in art. In a similar, but aphoristic and poetic way, Chema Cobo offers us a delightful array of reflections on art, language, culture and life, while África Vidal closes the volume with a witty, scrupulous and at times mordant glossary of common postmodern terms.

The result is an engaging volume that will be of interest to readers in the fields of English philology, sociology, philosophy and art. The updated bibliography (816 entries), compiled by África Vidal and Román Álvarez, is one of the most complete bibliographies on postmodernism and related subjects to date.

Ovidio Carbonell

\title{
M. Carmen África Vidal Claramonte. Futuro anterior: reflexiones filológicas sobre el fin de siglo. Barcelona: Promociones y Publicaciones Universitarias, 1994, 157 pp.
}

One may think of the paradoxical implications of this suggestive title, Futuro anterior, as regards Spanish verbal inflexion (pretérito imperfecto also lends itself to fruitful combinations), or one could turn to the no less paradoxical speculations of Derrida's theory on the certain past quality of both present and future, and the relationship between past and future that, precisely, shape a rather inexistent present. Nevertheless, the feeling of a future that happened before bears the Nietzschean tinge of recurrence, as well as the postmodern yield to exhaustion. Everything has already been said; cynicism and a playful curiosity should replace any search for essences or trascendence. The Holy Grail at the turn of the millennium is found empty; its existence as a commodifiable artifact is all that remains.

Far from indulging herself in yet another circular piece of speculation, África Vidal embarks on a journey across some of the most relevant areas of contention in contemporary cultural debates. The first chapter evokes a post which is at the same time a beginning and an end. It is time to recapitulate what it is that we are left with, now that the clamour of postmodern speculation has somewhat faded. While postmodernism championed a fondness for narcissistic contemplation and homogeneity, it is also true that this attitude has favoured a climate of tolerance as yet unknown, though clearly insufficient. Certain trends of postmodern thought find it inappropriate, or even impossible, to pursue a political course of action.

What, then, is to be done? Is it possible to write history, deal with distinct identities, even follow a concrete educational programme? Futuro anterior searches for answers to these questions. It is, above all, a book about the teaching of literature as well as how to teach students to read the world around. If postmodernism left many questions unanswered, it is from the mechanisms of postmodern thought and its critics that a proper course of action could arise. Therefore, the first chapter is an assessment of those postmodern characteristics that have proved to be most influential or beneficial, as well as an appraisal of some of its most acute criticisms. The second chapter comes to grips with the reality of teaching after postmodernism: the encounter of opposing, even conflicting attitudes within academic institutions, and the possibility of achieving a critical and fruitful rather than destructive thinking. 
Reflecting on the world as a text poses a good number of questions on language. M. Carmen Africa Vidal then turns to the issue of creating a text: the role of the author, his/her dissolution in the ocean of repetitions and references that shape contemporary fiction, its ultimate expression being the computer-assisted hypertext. Originality, identity, the historical subject may all lose their meaning, or at least alter it substantially. Yet it is a characteristic of contemporary culture that there is no single, closed text. Narrative texts elude a linear sequence, and their author appears disseminated, disintegrated in a plurality of textual layers, most of which cannot be clearly assigned to a single, masterful subject. A paradoxical situation is revealed: despite its welcome tendency towards pluralism and the acceptance of the Other, the so-called death of the author may carry with it a tendentious homogenization, a "renaissance of the Same," to the disadvantage of distinct cultural identities. $\mathbf{M}^{\mathbf{a}}$ Carmen África Vidal warns against this and many other dangers of postmodern thought inadequately understood. The politics of language points towards the anomalous domain of power: as relevant as what is being said are those blank spaces that remain unuttered, those skipped meanings, the play on words, those imprecise garments that eventually become "the only way to gain access to the realm of ethics."

The last chapter displays the cultural paradoxes of these anxious times, drawing upon instances of popular and high culture, always interrelated. Cultural icons such as Madonna and relevant theorists such as the post-marxist critic Jameson, among many others, are the objects of a serious reflection on the fin-de-siecle cultural hotchpotch. Fashion, sex and love are some of the aspects examined, models of a contemporary society obsessed with nostalgia and simulacra.

In short, this perspicacious book, written in an at times cynical, but always concerned Borgesian style, offers an enjoyable and assertive insight into the predicament of culture studies. It may help us not to waste "the postmodern occasion," as it has been termed, but, above all, through post-technological icons and signifiers, it will surely give us matter for reflection and perhaps a new attitude towards life and books, the immense library of everyday experience.

Ovidio Carbonell

\section{Walt Whitman. Hojas de hierba: antología bilingüe. Trans. and notes Manuel Villar Raso. Madrid: Alianza Editorial, 1995, 276 pp.}

In a brief review like this one, very little that is new can be said about Leaves of Grass, one of the most frequently discussed works in the English language and one which has already been translated several times into Spanish by poets and writers as famous as José Martí or Jorge Luis Borges. It therefore seems more advisable to focus on the values and intentions of the translation, and to abstain from reassessing the main traits of a book written by Whitman in 1855 and revised by him time and again.

Translation is characterized by what might be termed a double tension between the reproduction of the source text and the creation of a new text which seeks to attain a degree of efficiency and quality dictated by the target system conventions. In this 